\title{
The molecular basis of cognitive deficits in pervasive developmental disorders
}

\author{
Aditi Bhattacharya and Eric Klann ${ }^{1}$ \\ Center for Neural Science, New York University, New York, New York 10003, USA
}

\begin{abstract}
Persons with pervasive developmental disorders (PDD) exhibit a range of cognitive deficits that hamper their quality of life, including difficulties involving communication, sociability, and perspective-taking. In recent years, a variety of studies in mice that model genetic syndromes with a high risk of PDD have provided insights into the underlying molecular mechanisms associated with these disorders. What is less appreciated is how the molecular anomalies affect neuronal and circuit function to give rise to the cognitive deficits associated with PDD. In this review, we describe genetic mutations that cause PDD and discuss how they alter fundamental social and cognitive processes. We then describe efforts to correct cognitive impairments associated with these disorders and identify areas of further inquiry in the search for molecular targets for therapeutics for PDD.
\end{abstract}

Normal early childhood development requires a myriad of molecular and cellular processes that are exquisitely balanced and tightly regulated. In contrast, in pervasive developmental disorders (PDD), normal neurodevelopment is either delayed or severely compromised (DSM-IV, American Psychiatric Association 2000). The ICD-10 nomenclature of the World Health Organization (WHO) designates this set of conditions as Autism Spectrum Disorders (ASD), a more frequently used term (WHO 2004). It is estimated that early onset intellectual disability (ID), which is highly co-morbid with an existing PDD diagnosis, affects $\sim 1 \%$ of the global population. PDD is perhaps the most expensive of all human disorders, outpacing cancer and psychiatric diseases (Ropers 2010) because the affected individual requires a combination of behavioral and clinical therapy as well as long-term care. The current diagnostic and statistical manual of mental disorders IV (DSM-IV) defines PDD as an umbrella category comprising five major conditions: (1) autism, including both genetic and idiopathic causes; (2) Asperger's Syndrome; (3) Rett's Syndrome; (4) childhood disintegrative disorder (CDD), a rare, regressive late-onset developmental delay with unknown functional basis; and (5) PDD-NOS, which encompasses atypical autistic cases.

An individual is diagnosed with PDD when behavioral abnormalities are observed in any one or all of the three core domains: social development, communication, and repetitive behavior/ obsessive interests (Baron-Cohen 2004). This "triad of deficits" can be thought of as an overall "problem" in social cognition. The severity of the condition may range from inability to process simple cues such as gaze fixation to complex operations such as biologic motion sensing, triadic attention sharing, and behavioral requesting (McPartland et al. 2011). The intellectual quotient (IQ) of individuals with PDD varies across a broad range, but is a strong predictor of the expression of the disorder, the level of cognitive abilities observed, and treatment outcomes (Baron-Cohen 2004). A plethora of imaging studies conducted with autistic and nonautistic children in a variety of contexts have helped identify several key difficulties with higher order cognitive processing. First, it is believed that deficits occur due to altered development of key brain areas involved in the processing of social and operational information (see McPartland et al. 2011 for details).

\footnotetext{
'Corresponding author

E-mail eklann@cns.nyu.edu

Article is online at http://www.learnmem.org/cgi/doi/10.1101//m.025007.111.
}

Second, there is mounting evidence that points to altered connectivity between these regions and other brain areas responsible for the expression of social behavior, anxiety, and emotional responses. It is here that nonhuman models (mainly mouse) of cognitive dysfunction hold promise, because genetic manipulations that alter the connectivity and architecture of discrete brain areas can be done with relative ease. However, the major challenge has been to recreate cognitive dysfunction in these models of PDD.

The three major criteria that have made mice the system of choice to model cognitive dysfunction associated with PDD are: (1) the relative ease of manipulating genes, (2) a reasonably good approximation of human behaviors, and (3) mice are a social species that engage in a variety of social interactions, parenting, communal nesting, and aggressive territory marking behaviors (Crawley 2007). In the past decade, behavioral neuroscientists have worked intensely with clinical experts on PDD to devise a large battery of tests that measure social interactions and the expression of stereotypic behavior. These tests are being used extensively to characterize a myriad of gene-behavior questions related to autism and associated PDDs (see Silverman et al. 2010a for a detailed review). The expression of empathy and the attributing of "theory of mind" capabilities to nonhuman species has become an intensely debated topic. Recent findings demonstrate that rodents may have some form of "emotional contagion-like or empathy-like responses" (Ben-Ami Bartal et al. 2011; Panksepp and Lahvis 2011), which if shown to be impaired in PDD models reliably, will considerably aid future research. Meanwhile, traditional tests of learning and memory are being utilized routinely to assess the cognitive outcomes of gene manipulations in mouse models of PDD. These include spatial learning and memory using the Morris water maze (MWM), Y-maze, and T-maze; emotional and associative memory using passive avoidance and fear conditioning paradigms, and attention-related sensorimotor gating using paired pulse inhibition (PPI), go/no go tests, and multiple choice serial reaction tests (Crawley 2007; Bishop and Lahvis 2011). A point to be noted is that these tests measure operational learning and memory, which often is impaired only when there is mild to profound mental retardation accompanying a PDD diagnosis in humans.

So how did the view that PDD has a genetic basis come about? Work by eminent psychiatrists and psychologists like Rutter, Wing, and Baron-Cohen to name a few, in the 19601980s, laid the groundwork for the codification of PDD, put forth 
theories to explain the observed deficits, and categorized the large variation in behavioral abnormalities observed (Rutter 1970; Rutter and Bartak 1973; Wing 1981; Baron-Cohen 2010). At this point, treating PDD was considered solely the purview of behavioral interventionists because it was deemed largely intractable to medical treatment. Meanwhile, many genetic conditions such as fragile $\mathrm{X}$ syndrome, tuberous sclerosis complex, neurofibramatosis, and Down syndrome were being similarly medically and molecularly characterized, and co-morbidities with PDD were observed. These observations helped introduce the notion that many neurodevelopmental deficits in PDD might be due to altered molecular function and/or architecture of neural systems. Thus, by the turn of the 21st Century, the unifying hypothesis was that autism and other PDDs have a strong genetic basis, and that it was time to consider the condition and treatment from a genetic and molecular point of view.

The shifting views of PDD came at a moment when tremendous innovation and progress in molecular genetics and cell biology already had been achieved. Not only was the human genome sequenced, uncovering a plethora of de novo mutations and copynumber variations in PDD, but the functions of many proteins were being discovered with the help of animal models where one could study the effects of gene deletion and overexpression. In parallel, the cell biology of transcription, translation, protein trafficking, metabolism, and perhaps most importantly, signaling pathways in the context of neuronal and circuit function had been studied in great detail. We now are witnessing a convergence of causality, with multiple syndromic conditions impacting common molecular and cellular processes as well as many candidate genes altered in PDD identified as mediators of these processes (Kelleher and Bear 2008; Hoeffer and Klann 2010). Though this phenomenon augurs well for therapies that target common affected pathways in PDD, the information on how cognitive abnormalities are rectified by manipulating molecular processes oftentimes get lost amidst the sea of "rescue" studies that focus on rectifying signaling and neuronal markers rather than behavioral abnormalities. This review is organized according to pathways that are vital to normal neuronal function at a cellular and molecular level and how disruption of these processes in PDD are associated with social and cognitive dysfunction. The aim of this review is to describe the current state of (1) mouse models of human genetic syndromes co-morbid with PDD that are available and successfully mimic the social and cognitive behavioral abnormalities of PDD; (2) how these social and cognitive behaviors (largely limited to cortical areas of the brain) are disturbed by the molecular and cellular abnormalities; and (3) identify gaps in our current understanding that require further attention.

\section{DNA regulation}

The genetic bases of several PDD associated conditions frequently involve mutations in genes involved in DNA regulation. These include homeobox pattern regulators like Aristaless, Hox1A, and SATB2; epigenetic enzymes including EHMT1 and DNA-binding proteins including NSD1 and nuclear factor 1/X (Betancur 2011; van Bokhoven 2011). The most intensely studied condition involving improper DNA regulation as the core molecular abnormality is Rett Syndrome (RTT), which is caused by the loss of Mecp2, a transcription factor that binds methyl CpG modifications on DNA (Chen et al. 2001; Guy et al. 2001). RTT is one of the five main divisions of the PDD category in DSM IV. However, it is proposed to be excluded in DSM-V because patients often display autistic traits only briefly during early childhood and the RTT diagnosis is essentially etiologic rather than behavioral (www.dsm5.org). Complete deletion of Mecp2 is embryonic lethal; therefore, multiple lines of conditional knockout mice have been generated targeting Mecp2 in specific neuronal subpopulations as well as knockin mice with full-length Mecp2-containing, RTT-specific mutations (for review, see Calfa et al. 2011). Mice carrying a Mecp2 truncation exhibited increased confrontation tendency in the tube test of social interaction (Shahbazian et al. 2002). However, these mice displayed normal fear-conditioning responses and MWM performance. Abnormal home-cage behavior, nesting, and social approach have been reported for another mouse model with RTT mutation Mecp2-308, with no differences in either aggression or exploration of novel inanimate stimuli (Moretti et al. 2006). Interestingly, conditional deletion of Mecp2 in specific brain areas resulted in specific behavioral phenotypes. For example, a forebrain-specific deletion of Mecp2 exhibited increased anxiety and social behavior, whereas acquisition and consolidation of associative fear memory remained intact (Gemelli et al. 2006). Deletion of Mecp2 in dopaminergic and noradrenergic neurons did not result in cognitive defects, but severely impaired locomotion (Samaco et al. 2009). Serotonergic system-targeted silencing of Mecp2 caused increased aggression, while deletion of Mecp2 in the amygdala resulted in heightened anxiety and impaired associative fear memory (Adachi et al. 2009; Hutchinson et al. 2012). Interestingly, increasing the gene dosage of Mecp2 via duplication causes a severe form of PDD called MECP2 duplication syndrome, and model mice with global increases in the protein exhibited increased anxiety, impaired contextual fear memory, and deficits in novel object recognition (Collins et al. 2004; Na et al. 2012). Finally, targeted deletion of Mecp2 in GABAergic neurons recapitulated all of the social impairments associated with RTT (Chao et al. 2010). Therefore, cognitive dysfunction in RTT may be due to problems in local populations of inhibitory neurons. At present, none of the experimental approaches have fully reversed RTT-associated cognitive phenotypes, although breathing and locomotor impairments have been rescued in RTT model mice (see Guy et al. 2007; Calfa et al. 2011). Social interaction impairments and increased anxiety due to duplication of Mecp2 have been counteracted successfully by decreasing Crh and its receptor (Samaco et al. 2012).

Rubinstein-Taybi syndrome (RTS) is an uncommon autosomal dominant syndrome that is associated with PDD-like features and is caused by mutations in the CREB-binding protein 2 (CREB-BP 2) gene (Betancur 2011). CREB-BP 2 is a ubiquitously expressed histone acetyltransferase with scaffolding, transcriptionfactor recognition, and transcription regulation functions. Because its primary association is with CREB, CREB-BP 2 interacts with a wide variety of transcription factors and has been shown to be vital for synaptic plasticity and neurodevelopment (Josselyn 2005). Transgenic mice expressing truncated CREB-BP 2 exhibit impaired spatial learning in the MWM and defective contextual fear memory, but normal cued fear memory (Wood et al. 2005a). An earlier study showed that these mice display enhanced anxiety, impaired novel object recognition, and sensorimotor gating deficits (Alarcón et al. 2004). To model effects of impaired CREB-BP function during development, mice haploinsufficient for $C R E B-B P 2$ were generated and it was demonstrated that neonates have altered ultrasonic vocalizations (USVs), indicating a role for this enzyme in early cognitive development (Wang et al. 2010a). Precisely how the function of CREB-binding proteins are functionally linked to intellectual deficits associated with RTS has not been determined. However, inhibiting HDAC activity can ameliorate certain behavioral phenotypes displayed by RTS model mice, while either increasing cAMP signaling with Rolipram or transgenic expression of a constitutively truncated CREB-binding protein results in deficits in MWM and contextual fear conditioning tasks (Bourtchouladze et al. 2003; Alarcón et al. 2004; Wood et al. 2005a). 


\section{RNA regulation}

Being highly polarized with extensive elaborations, neurons face a supply-chain problem of delivering newly synthesized proteins to the appropriate synaptic locations in response to rapid, activitydependent changes in signaling cascades. To overcome this problem, neurons utilize the phenomenon of local axonal and dendritic translation in close proximity to synaptic sites. Therefore, mRNA trafficking and translational control impacts not only synaptic plasticity, but neural circuits as well, and these processes have been found to be dysregulated in a subset of PDDs (Liu-Yesucevitz et al. 2011). The most extensively studied of this type of PDD is fragile X syndrome (FXS), which is caused by an uncontrolled expansion of CGG repeats at the $5^{\prime}$ end of the Fmr1 gene, causing promoter hypermethylation and subsequent loss of expression of fragile $\mathrm{x}$ mental retardation protein (FMRP). FMRP mediates different aspects of RNA metabolism, including trafficking of RNP particles, translation of specific mRNA transcripts via regulation of translation initiation and elongation, and targeted degradation via the RISC complex (Jin et al. 2004; Park et al. 2008; Kao et al. 2010; Melko and Bardoni 2010). FXS model mice, where the Fmr1 gene has been deleted, have been exhaustively studied and shown to display the "triad of deficits" features associated with PDD (Gross et al. 2012). Intriguingly, most pharmacological and genetic rescue strategies have opted to evaluate hyperactivity, motor skill learning, and the seizure susceptibility of FXS model mice, with only recent reports highlighting the effect of such molecular manipulations on social interactions (Mines et al. 2010; Goebel-Goody et al. 2012; Rotschafer et al. 2012). In spite of our current insights into the pathophysiology of FXS, no treatment strategy has as yet attempted to rescue disease phenotypes by regulating translational control elements directly. Current therapeutic efforts are focused on manipulating cell surface receptors and signaling kinases far upstream of translation (Gross et al. 2012). FMRP is a member of the RNA-binding protein family, of which mutations in another member, Fmr2 or AFF-2, causes FRAXE condition, which is one of the most common forms of nonsyndromic X-linked mental retardation (Stettner et al. 2011). Because Fmr2 knockout mice show impaired fear conditioning, it is likely that dysregulated RNA metabolism also is responsible for many features of FRAXE (Gu et al. 2002). In the future, it may be pertinent to explore strategies involving direct modulation of translation regulatory elements to holistically address impairments observed in FXS, FRAXE, and related conditions.

Other translation regulators also have been implicated in the pathophysiology of PDD, including eukaryotic initiation factor $4 \mathrm{E}$ (eIF4E) (Neves-Pereira et al. 2009), faulty RNA editing mechanisms of serotonin receptor type 2C (Morabito et al. 2010) leading to Prader-Willi-like features, and defects in correct splicing machinery contributing to some forms of Angelman and Down syndromes (Sartori et al. 2008; Shi et al. 2008). In summary, though the concept of dysregulated RNA translation and dynamics is well established in the eitiology of multiple PDD conditions, the precise contribution of these molecular processes in cognition remains to be comprehensively demonstrated.

\section{Metabolism and energetics}

Behavioral research focusing on metabolic disruptions has lagged despite early indications that nearly 5\% of all PDD cases are caused by inborn errors of metabolism (Manzi et al. 2008). For example, individuals with Lesch-Nyhan's Syndrome (LNS), which is caused by a deficiency of the hypoxanthine-guanine-phosphoribosyltransferase (HGPRT) enzyme that plays a key role in the purine salvage pathway, displays multiple behavioral phenotypes that include self-mutilating behavior and mental impairment (Nyhan et al. 2000). Although a mouse model of HGPRT deficiency exists, neurological phenotypes have not been studied extensively (Bertelli et al. 2009; Ceballos-Picot et al. 2009). Another syndrome with defective nucleotide metabolism is adenylosuccinate lyase defiency (ADSL), which presents with global developmental delay akin to Angelman syndrome, including severe speech deficits, seizures, happy disposition, hyperactivity, and stereotypies (Gitiaux et al. 2009). Biotinidase deficiency is known to be associated with autism (Betancur 2011), with the first neurological assessments of a mouse model being conducted recently (Pindolia et al. 2011). In contrast, errors in cholesterol metabolism and the association with PDD have been extensively studied. This may be due to the well-established importance of lipid-protein interactions in signaling, trafficking, and synaptic transmission, and because of the role of cholesterol in myelination and neurite development (Korade and Kenworthy 2008). Inhibitors of cholesterol synthesis have been shown to affect acquisition of conditioned eyeblink response in rats (Xu et al. 1998; O'Brien et al. 2002). The clinical correlate of these studies is Smith-Lemli-Opitz syndrome (SLOS), which is caused by the genetic deletion of 7-dehydrocholesterol reductase gene resulting in an inability to convert 7-dehydrocholesterol to cholesterol. There is an extremely high prevalence of autism in SLOS patients (Sikora et al. 2006) and SLOS mouse models are available (Xu et al. 2011). Therefore, it will be very relevant to investigate the cognitive dysfunctions in SLOS model mice.

In contrast to metabolic impairments, the relationship between oxidative stress, mitochondrial function, and cognition has been studied widely (see Massaad and Klann 2011 for detailed review). Multiple studies have focused on the effects of reactive oxygen species (ROS) and mitochondrial dysfunction on several forms of memory (Hu et al. 2009; Otte et al. 2011), but there are very few reports involving the role of either mitochondrial-derived or other sources of ROS in social interactions or behavioral inflexibilty (Zhuravliova et al. 2009; Rammal et al. 2010; Kamat et al. 2011). An insightful study was done by Roubertoux et al. (2003), which demonstrated a striking effect of mitochondrial DNA polymorphism (and presumably mitochondrial dysfunction) on cognition in mice. Over the past few years, evidence has been mounting that ROS and oxidative stress play a critical role in the manifestation of PDD. Numerous examples have been recorded of humans suffering from either syndromic or idiopathic PDD who show elevated levels of mitochondrial ROS and bioenergetic stress markers such as high levels of circulating lactate, pyruvate, carnitine, and ubiquinone (Palmieri et al. 2010; Chauhan et al. 2011; Sajdel-Sulkowska et al. 2011; Frustaci et al. 2012; Rossignol and Frye 2012). It is speculated that $20 \%$ of all autistic cases may be caused to some extent by mitochondrial dysfunction, and a large number of de novo mutations implicated in PDD affect either mitochondrialgenes or nuclear origin genes encoding proteins involved in the electron transport chain and other oxidation-related processes (see Dhillon et al. 2011 for the multiple ways in which mitochondrial and oxidative dysfunction is associated with PDD). Well-studied monogenetic PDD conditions such as FXS and RTT have high levels of oxidative stress, and there is evidence of a partial rescue of biochemical markers and nonverbal communication in RTT patients with the administration of $\omega-3$ polyunsaturated fatty acids (Ross-Inta et al. 2010; Leoncini et al. 2011; De Felice et al. 2012). "Metabolomics" and oxidative stress are fast-emerging subdisciplines in PDD; however, the precise role of mitochondria and ROS in cognitive dysfunction remains to be unraveled, as does the efficacy of treatments based on antioxidants. 


\section{Transport}

Studies of the cell biology of the endoplasmic reticulum (ER) and the Golgi apparatus and their functions, which include posttranslational modifications, protein folding, and protein trafficking, has resulted in a wealth of knowledge concerning how the cell manages the protein assembly line and delivery of proteins to the appropriate locations (Lodish et al. 2008). There are numerous examples of how impaired post-translational processing, protein folding, and protein trafficking underlie inherited human diseases (Hebert and Molinari 2007) including lung emphysema, cardiac arrhythmia, liver failure, and Parkinson's disease. Among PDDs, there are fewer examples, usually in rare genetic syndromes that have some overlap with autism (Betancur 2011). The most direct association of a PDD-candidate gene and protein trafficking comes from studies of oligophrenin 1 (OPHN1). OPHN1 is a member of the BAR domain superfamily that organize membrane curvature and signaling assemblies on membranes (Qualmann et al. 2011). OPHN1 knockout mice were shown to display deficits in spatial memory and social interactions (Khelfaoui et al. 2007). Another candidate gene for PDD is calcium-dependent activator protein for secretion 2 (CADSP2), which mediates exocytosis of dense core vesicles by interaction with ARF-family GTPases (Sadakata et al. 2012). Alternative splicing of CADSP2 mRNA has been reported in autistic individuals, and CADSP2 knockout mice were shown to exhibit impaired social interaction, hyperactivity, hesitation to explore a novel object, and most importantly, maternal neglect of newborns (Sadakata et al. 2007). Unfortunately, there is a paucity of studies aimed at evaluating the effect of improper protein trafficking on cognition in PDD.

There is evidence that correct protein trafficking is important for cognition. For example, deletion of the glutamate receptor interacting protein GRIP in mice results in impairments in PPI, novel object recognition, and sociability (Mejias et al. 2011). In addition, recent studies strongly suggest that insulin-like growth factor 2 (IGF2) enhances memory consolidation (Alberini and Chen 2012). IGF2 has been implicated in Beckwith-Wiedermann and Silver-Russell syndromes, and in most cases, signals via the IGF2 receptor, a mannose-6-phosphate receptor that is important for transporting lysosomal acid hydrolase precursors from the Golgi apparatus to the lysosome (Laureys et al. 1988; Kent et al. 2008). Deletion of dysbindin-1 protein, which plays a role in the post-endocytic trafficking of G-protein-coupled receptors (Marley and von Zastrow 2010), results in hyperactivity and deficits in spatial learning (Cox et al. 2009; Karlsgodt et al. 2011). Moreover, the molecular mechanisms underlying the cognitive deficits in individuals with mutations in the neuroligins may stem from their abnormal trafficking. It was shown that mutations in both neuroligin 3 and neuroligin 4 that are associated with PDD cause improper folding of each protein, resulting in ER retention and stress (Zhang et al. 2009; Fujita et al. 2010). ER stress also appears to play a role in tuberous sclerosis complex (TSC). Disruption of the TSC1/TSC2, which enhances mTORC1 signaling, results in ER stress, which is thought to be a response to limit mTORC1 activity (Di Nardo et al. 2009). Therefore, though we have extensive knowledge of how protein folding and trafficking is executed and regulated, it is only very recently that its role in relation to PDD is being identified and appreciated.

\section{Signaling and cell-to-cell communication}

The synapse has been the primary focus of understanding the molecular architecture in neuronal systems. Not surprisingly, this has generated a wealth of information, not only about signaling pathways underlying synaptogenesis, synapse maturation, and synap- tic plasticity, but also regarding mechanisms that allow the preand post-synaptic structures to interact. Neurological disorders involving dysregulated proteins in the synaptic proteome has been implicated in over 100 human diseases (Grant 2012), of which PDDs are a prominently represented subset. Of these, behavioral data examining cognitive function is available for only a handful of the genetic mutations associated with PDD, although in some cases, knockout mouse models exist. Table 1 lists the molecules that have a high correlation to PDD and other related disabilities, and the current state of literature regarding their association with cognitive deficits in the mutant mice for each gene product.

\section{Degradation}

Activity-dependent breakdown of "memory proteins" coupled with the synthesis of new ones is believed to be critical for the appropriate expression of synaptic plasticity, neural connectivity, and ultimately, memory consolidation. It has been known for nearly $60 \mathrm{yr}$ that proper protein synthesis is required for memory consolidation, but it is only in the past decade that the importance of protein degradation in memory formation has been realized (Lopez-Salon et al. 2001; Lee et al. 2008). Protein degradation can occur via three routes: (1) the ubiquitin-proteasome system (UPS) that degrades the majority of short-lived proteins, (2) lysosomal degradation that targets organelles and membrane proteins, and (3) autophagy, a specialized process in which bulk cytoplasmic content is engulfed within double-membrane vesicles and then targeted to lysosomes (Bingol and Sheng 2011). Disruption of each of these three processes has been implicated in the pathophysiology of human diseases, but only the UPS has been shown thus far to be affected in PDD (Tai and Schuman 2008; Betancur 2011). The prime example of a PDD caused by disruption of the UPS is Angelman syndrome (AS), which most often occurs when the UPS executor protein ubiquitin ligase E6-AP, also known as UBE3A, is absent due to mutations in the maternal copy of the UBE3A gene (Lalande and Calciano 2007).

Cognitive problems in AS individuals include language impairments, happy demeanor, hyperexcitability, and severe developmental delays (Pelc et al. 2008). AS mouse models with a deletion of $U B E 3 A$ alone were reported to have deficits in spatial memory in the MWM and in contextual fear memory along with increased seizure susceptibility (Jiang et al. 1998; Miura et al. 2002). Genetic enhancement of CaMKII activity in AS model mice prevents deficits in spatial memory in the MWM, contextual fear memory, and reduces susceptibility to audiogenic seizures (van Woerden et al. 2007). In addition, impairments in contextual fear memory in AS model mice recently was shown to be counteracted by suppressing neuregulin1-Erb4 signaling (Kaphzan et al. 2012). Interestingly, some social behavior and anxiety features in AS may not be due to the lack of UBE3A expression alone, but may also require deletions of additional genes on chromosome 15 that are known to occur in $70 \%$ of AS patients (Jiang et al. 2010; Allensworth et al. 2011). Interestingly, transgenic mice with increased expression of UBE3A, which models duplications and triplications of $15 q 11-13$, where the UBE3A gene resides, were shown to have defective social interactions and a lower frequency of ultrasonic vocalizations (Smith et al. 2011). A related PDD condition of X-linked Angelman-like syndrome caused by mutations in the $S l c 9 a 6$ gene is reported to have disruptions in endosomal-lysosomal functions (Strømme et al. 2011). Additional components of the degradation machinery have been linked to decreased cognitive ability. For example, mice with a deletion of ubiquitin C-terminal hydrolase L3 gene (UchL3) display impaired passive avoidance behavior and working memory (Wood et al. 2005b). Future research focused on directly 
Table 1. Proteins involved in signaling networks and cell-to-cell communication with a high correlation to PDD

\begin{tabular}{|c|c|c|c|c|}
\hline Molecule & Type of PDD & Mouse model phenotypes & Rescue strategies & Reference \\
\hline \multicolumn{5}{|c|}{ Signaling, receptors, and ion channels } \\
\hline $\begin{array}{l}\text { Angiotensin receptor II type } \\
2 \text { (AGTR2) }\end{array}$ & $\begin{array}{l}\text { Nonsyndromic X-linked } \\
\text { ID }\end{array}$ & $\begin{array}{l}\text { Cognitive: } \downarrow \text { spatial memory in } \\
\text { MWM } \\
\downarrow \text { performance one-way active } \\
\text { avoidance task } \\
\text { Social: } \text { not known }\end{array}$ & & Maul et al. 2008 \\
\hline AMPA Receptor 3 (GRIA3) & $\begin{array}{l}\text { Nonsyndromic X-linked } \\
\text { ID }\end{array}$ & $\begin{array}{l}\text { Cognitive: no effect in MWM and } \\
\text { Y-maze } \\
\text { Social: } \uparrow \text { social interaction and } \\
\text { aggression }\end{array}$ & & $\begin{array}{l}\text { Betancur 2011; } \\
\text { Adamczyk et al. } \\
2012\end{array}$ \\
\hline B-Raf, K-Ras & $\begin{array}{l}\text { Cardio-facio-cutaneous } \\
\text { syndrome, Noonan } \\
\text { syndrome, Castello } \\
\text { syndrome }\end{array}$ & $\begin{array}{l}\text { KO model exists, but no behavioral } \\
\text { analysis at this time }\end{array}$ & $\begin{array}{l}\text { MEK inhibitor } \\
\text { ameliorated the } \\
\text { embryonic lethality } \\
\text { and cardiac defects }\end{array}$ & $\begin{array}{l}\text { Nava et al. 2007; Chen } \\
\text { et al. 2010; Wu et al. } \\
2011\end{array}$ \\
\hline $\begin{array}{l}\mathrm{Ca}^{2+} \text { channel, } \\
\text { voltage-gated, } \alpha 1 C \\
\text { (CACNA1C) }\end{array}$ & Timothy syndrome & $\begin{array}{l}\text { Cognitive: } \uparrow \text { tone-cued and } \\
\text { contextual fear } \\
\text { Social: } \downarrow \text { USVs } \\
\downarrow \text { social approach, preference and } \\
\text { exploration }\end{array}$ & $\begin{array}{l}\text { Not examined in } \\
\text { neuronal systems } \\
\text { Deletion of AKAP150 } \\
\text { rescues arrhythmias }\end{array}$ & $\begin{array}{l}\text { Splawski et al. 2004; } \\
\text { Bader et al. 2011; } \\
\text { Cheng et al. 2011 }\end{array}$ \\
\hline $\begin{array}{l}\text { Cylcin-dependent protein } \\
\text { Kinase-like } 5 \text { CDKL5 }\end{array}$ & $\begin{array}{l}\text { Rett Syndrome-like with } \\
\text { spasms and ID }\end{array}$ & No behavioral analysis at this time & & Weaving et al. 2004 \\
\hline \multirow[t]{2}{*}{$\begin{array}{l}\text { Fibroblast Growth Factor } \\
\text { Receptor } 1 \text { (FGFR1) }\end{array}$} & \multirow[t]{2}{*}{ Autism } & $\begin{array}{l}\text { Cognitive: } \downarrow \text { spatial memory in } \\
\text { MWM } \\
\downarrow \text { PPI in FGFR1 Tg }\end{array}$ & $\begin{array}{l}\text { Agonists to FGFR1 } \\
\text { social memory } \\
\text { and } \downarrow \text { anxiety }\end{array}$ & \multirow[t]{2}{*}{$\begin{array}{l}\text { Zhao et al. 2007; } \\
\text { Klejbor et al. 2009; } \\
\text { Rudenko et al. 2010; } \\
\text { Rubenstein } 2011\end{array}$} \\
\hline & & $\begin{array}{l}\text { Social: } \downarrow \text { interaction } \\
\text { No effect on grooming in } \\
\text { FGFR1 Tg }\end{array}$ & $\begin{array}{l}\text { Qietiapine } \uparrow \text { social } \\
\text { interaction in FGFR1 } \\
\mathrm{Tg}\end{array}$ & \\
\hline Neurofibromin 1 & Neurofibromatosis & $\begin{array}{l}\text { Cognitive: } \uparrow \text { radial arm maze errors } \\
\downarrow \text { performance in delayed } \\
\text { nonmatch to sample task } \\
\text { Social: not known, but NF1 } \\
\text { mediates depressive behaviors }\end{array}$ & $\begin{array}{l}\text { Picrotoxin administration } \\
\text { normalizes working } \\
\text { memory deficits }\end{array}$ & $\begin{array}{l}\text { Shilyansky et al. 2010; } \\
\text { Li et al. } 2012\end{array}$ \\
\hline $\begin{array}{l}\text { Phosphatase and Tensin } \\
\text { Homolog on } \\
\text { Chromosome } 10 \text { (PTEN) }\end{array}$ & $\begin{array}{l}\text { PTEN hamartoma } \\
\text { syndrome, } \\
\text { Lhermitte-Duclos } \\
\text { disease }\end{array}$ & $\begin{array}{l}\text { Cognitive: } \downarrow \text { PPI } \\
\uparrow \text { seizure susceptibility } \\
\text { Social: } \\
\downarrow \text { social approach } \\
\downarrow \text { social recognition and novelty } \\
\text { discrimination } \\
\downarrow \text { nesting behavior } \\
\uparrow \text { anxiety }\end{array}$ & $\begin{array}{l}\text { 5-d rapamycin treatment } \\
\text { for } 4 \text { wk improved } \\
\text { anxiety, seizure, and } \\
\text { social phenotypes }\end{array}$ & $\begin{array}{l}\text { Kwon et al. 2006; Zhou } \\
\text { et al. } 2009\end{array}$ \\
\hline Rac/cdc42 GEF & X-linked ID & $\begin{array}{l}\text { Cognitive: } \downarrow \text { reversal learning in } \\
\text { MWM }\end{array}$ & & Ramakers et al. 2012 \\
\hline Shank $1 / 2 / 3$ & $\begin{array}{l}\text { Autism, Asperger } \\
\text { syndrome, Phelan- } \\
\text { McDermid syndrome }\end{array}$ & $\begin{array}{l}\text { Cognitive: Shank } 1 \mathrm{KO} — \text { no deficits } \\
\text { Shank } 2 \text { KO-not known } \\
\text { Shank } 3 \mathrm{KO}-\downarrow \text { NOR, no effect in } \\
\text { MWM, fear conditioning, } \uparrow \text { PPI } \\
\text { startle latency, probability } \\
\text { Social: Shank } 1-\downarrow \text { social } \\
\text { interaction, } \downarrow \text { USVs, } \uparrow \text { anxiety } \\
\text { Shank } 2 \text { KO- not known } \\
\text { Shank } 3 \text { KO- }-\downarrow \text { juvenile reciprocal } \\
\text { interaction, } \downarrow \text { social } \\
\text { investigation, } \uparrow \text { aggressive } \\
\text { episodes, } \uparrow \text { grooming, no effect in } \\
\text { three chambered social arenas }\end{array}$ & & $\begin{array}{l}\text { Bozdagi et al. 2010; } \\
\text { Kumar 2010; } \\
\text { Silverman et al. } \\
\text { 2010b; Wang et al. } \\
\text { 2010b; Bangash } \\
\text { et al. 2011; Wöhr } \\
\text { et al. 2011; Yang } \\
\text { et al. 2012 }\end{array}$ \\
\hline $\begin{array}{l}\text { Sodium channel, } \\
\text { voltage-gated, type I, } \\
\alpha(\text { SCN1A) }\end{array}$ & $\begin{array}{l}\text { Dravet syndrome with } \\
\text { PDD }\end{array}$ & $\uparrow$ myoclonic seizures & & Ogiwara et al. 2007 \\
\hline $\begin{array}{l}\text { Solute carrier family } 9 \\
\quad \text { (sodium/hydrogen } \\
\text { exchanger), member } 6 \\
\text { (SLC9A6) }\end{array}$ & $\begin{array}{l}\text { Angelman-like syndromic } \\
\text { X-linked ID }\end{array}$ & $\begin{array}{l}\text { Cognitive: No changes in spatial } \\
\text { object memory } \\
\text { Other behaviors not examined } \\
\text { as yet }\end{array}$ & & Strømme et al. 2011 \\
\hline
\end{tabular}


Table 1. Continued

\begin{tabular}{|c|c|c|c|c|}
\hline Molecule & Type of PDD & Mouse model phenotypes & Rescue strategies & Reference \\
\hline $\begin{array}{l}\text { Synaptic Ras GTPase } \\
\text { activating protein } 1 \\
\text { (SYNGAP1) }\end{array}$ & Nonsyndromic ID & $\begin{array}{l}\text { Cognitive: } \downarrow \text { working and reference } \\
\text { memory } \\
\downarrow \text { spontaneous alternation in } \\
\text { T-maze } \\
\text { No change in object recognition } \\
\uparrow \text { execution of learned operant } \\
\text { behavior } \\
\downarrow \mathrm{PPI} \\
\text { Social: } \downarrow \text { social memory and social } \\
\text { isolation }\end{array}$ & & $\begin{array}{l}\text { Muhia et al. 2009, } \\
\text { 2010; Guo et al. } \\
2009\end{array}$ \\
\hline $\begin{array}{l}\text { Tuberous Sclerosis } 1 / 2 \\
\quad \text { (TSC) }\end{array}$ & Tuberous Sclerosis & $\begin{array}{l}\text { Cognitive: } \downarrow \text { context fear } \\
\text { discrimination } \\
\uparrow \text { errors of quadrant crossing in } \\
\text { MWM } \\
\text { Social: } \downarrow \text { social novelty and } \\
\text { interaction } \\
\text { Altered USVs }\end{array}$ & $\begin{array}{l}\text { Acute rapamycin } \\
\text { treatment improved } \\
\text { context discrimination } \\
\text { and MWM } \\
\text { performance }\end{array}$ & $\begin{array}{l}\text { Ehninger et al. 2008, } \\
\text { 2012; Young et al. } \\
\text { 2010; Chévere-Torres } \\
\text { et al. } 2012\end{array}$ \\
\hline \multicolumn{5}{|c|}{ Cell-to-cell communication } \\
\hline Neurexin1 (NRX 1) & $\begin{array}{l}\text { Autism, ID, Pitt- } \\
\text { Hopkins-like } \\
\text { syndrome-2 }\end{array}$ & $\begin{array}{l}\text { Cognitive: } \uparrow \text { responsiveness and } \\
\text { habituation to novelty } \\
\downarrow \text { startle in } 80-100 \mathrm{~dB} \text { range in } \\
\text { PPI } \\
\text { Social: } \uparrow \text { grooming behavior } \\
\downarrow \text { nesting behavior }\end{array}$ & & $\begin{array}{l}\text { Etherton et al. } 2009 ; \\
\quad \text { Laarakker et al. } 2012\end{array}$ \\
\hline $\begin{array}{l}\text { Contactin-associated } \\
\text { protein-like } 2 \text { (CNTNAP2) }\end{array}$ & $\begin{array}{l}\text { Cortical dysplasia-focal } \\
\text { epilepsy syndrome and } \\
\text { Pitt-Hopkins-like } \\
\text { syndrome-1 }\end{array}$ & $\begin{array}{l}\text { Cognitive: } \uparrow \text { seizures } \\
\text { Social: } \downarrow \text { USVs } \\
\quad \downarrow \text { social interaction } \\
\quad \downarrow \text { nesting behavior }\end{array}$ & $\begin{array}{l}\text { Risperidone relieves } \\
\text { abnormal nesting } \\
\text { behavior }\end{array}$ & $\begin{array}{l}\text { Peñagarikano et al. } \\
2011\end{array}$ \\
\hline Dystrophin (DMD) & $\begin{array}{l}\text { Duchenne and Becker } \\
\text { Muscular Dystrophy }\end{array}$ & $\begin{array}{l}\text { Cognitive: } \downarrow \text { spatial and object } \\
\quad \text { recognition }\end{array}$ & & $\begin{array}{l}\text { Vaillend and Ungerer } \\
\text { 1999, } 2004\end{array}$ \\
\hline $\begin{array}{l}\text { Neuroligins (NLG 1, 2, 3, } \\
\text { and 4) }\end{array}$ & $\begin{array}{l}\text { Autism, X-linked ID } \\
\quad \text { (NLG-4) }\end{array}$ & $\begin{array}{l}\text { Cognitive: NLG1 Tg: } \downarrow \text { memory } \\
\text { acquisition in MWM } \\
\text { NLG3 R451C Tg: } \uparrow \text { performance } \\
\text { MWM } \\
\text { Social: NLG1 Tg: } \downarrow \text { or altered USVs } \\
\text { NLG3 R451C Tg: } \downarrow \text { social } \\
\text { interaction behaviors } \\
\text { NLG2 KO: } \uparrow \text { anxiety } \\
\text { NLG2 Tg: } \downarrow \text { sociability } \\
\text { NLG3 KO: } \downarrow \text { USV, social novelty } \\
\text { preference } \\
\text { NLG4 KO: } \downarrow \text { reciprocal social } \\
\text { interaction }\end{array}$ & $\begin{array}{l}\uparrow \text { NLG1 improved social } \\
\text { behaviors in Fmr1 KO }\end{array}$ & $\begin{array}{l}\text { Tabuchi et al. 2007; } \\
\text { Hines et al. 2008; } \\
\text { Jamain et al. 2008; } \\
\text { Blundell et al. 2009; } \\
\text { Radyushkin et al. } \\
\text { 2009; Dahlhaus and } \\
\text { El-Husseini 2010; } \\
\text { Dahlhaus et al. 2010; } \\
\text { Fischer and } \\
\text { Hammerschmidt } \\
2011\end{array}$ \\
\hline
\end{tabular}

Key: $(\uparrow)$ increased; $(\downarrow)$ decreased; (MWM) Morris water maze; (USV) ultrasonic vocalization; (KO) knock-out; (Tg) knock-in or overexpression; (PPI) sensorimotor gating using paired-pulse inhibition paradigm.

regulating the UPS and lysosomal activity to ameliorate symptoms of Angelman syndrome and related conditions may be fruitful due to the strong causal relationship between dysregulated proteolytic mechanisms and PDDs.

\section{Summary}

It is now seems obvious that PDD in humans can be caused by genetic mutations, and mouse models serve as a critical tool for dissecting the social and cognitive dysfunction involved in these disorders. However, it is important to remember that basic research is focused primarily on syndromic forms of PDD that represent a minority of individuals afflicted with PDD. In addition, DSM IV and related manuals do not categorize many frequently studied syndromes under PDD. Instead, these conditions are defined as genetic syndromes associated with a "high-risk" of an accompanying PDD diagnosis. This may be because psychiatric diagnostic modules such as DSM IV are organized according to behavioral abnormalities rather than molecular mechanisms. In the future, devising a unified form of classification should help to mitigate the confusion prevalent regarding the precise definitions of such spectrum disorders.

The evaluation of social and cognitive deficits in mouse models of PDD were devised and standardized fairly recently. Thus, we now are witnessing an explosion of work characterizing the social and cognitive impairments in a variety of mouse models of syndromic autism. In some cases such as RTT, FXS, and AS, viable therapeutic options that could improve the quality of life of individuals with these syndromes are possible in the near future. Learning- and memory-based metrics such as MWM and fear conditioning have yielded important results in many other models (AS, RBS, etc.). However, certain key concerns persist that impede a more holistic advancement of the field.

First, there is a critical need to appreciate that genes underlying PDD work in concert and not in isolation. Therefore, not only do mutations of a gene and abnormal expression of the protein product affect the most direct cellular process/signaling pathway 
in which it is implicated, but they most certainly will have secondary effects in other processes/pathways as well. Because cognition is an outcome of the sum total of the function of neurons either autonomously or in a circuit, understanding the proteome, interactome, or metabolome in specific brain regions may offer additional targets through which therapeutic interventions can be designed. Second, because multiple effector molecules often impinge on a common cellular operation, as is the case with FMRP, PTEN, TSC1/2, mTORC1, eIF4E for translation (Kelleher and Bear 2008; Hoeffer and Klann 2010), it is possible that common cognitive deficits could be targeted via control of a common molecular pathway, such as a translational control molecule rather than an individual target for each. Third, it may be necessary to shift from intensely focused efforts on a handful of conditions such as RTT, FXS, and AS to PDDs associated with mitochondrial dysfunction because these likely represent a much larger set of afflicted individuals. On a related note, there is a paucity of data examining the role of oxidative stress in social cognition deficits in PDD, which is in contrast to studies of mouse models of aging and neurodegenerative disease (Massaad and Klann 2011). As was discussed earlier, in addition to mitochondrial dysfunction, altered DNA regulation and protein transport appear to play important roles in the manifestation of specific cognitive disruptions in mouse models of PDD, which should provide additional molecular targets for intervention (Sakurai et al. 2008). It is surprising that in some cases of PDD, such as Ras mutant mice modeling Noonan syndrome, well-developed mouse models are available that are being actively examined in fields outside of neuroscience, but have yet to be examined in detail for cognitive dysfunction. A final challenge is modeling gene-environment interactions that likely underlie the majority of idiopathic PDD cases, including CDD and PDD-NOS. Increasingly, experts in the field are recommending whole-genome assessments for all PDD cases, making it vital to have information on how perturbing each node of the interacting network impacts behavioral measures.

In summary, PDD represents a continuum of disorders caused by genetic mutations that results in impaired intracellular processes, triggering alterations in neuronal and circuit function, which ultimately impacts a number of behaviors. The utilization of mouse models to identify molecular targets represents the next wave of novel therapeutics for treatment of PDD.

\section{Acknowledgments}

This work was supported by National Institute of Health grants NS034007 and NS047384 (E.K.) and the FRAXA Research Foundation (A.B.). We apologize to our fellow scientists whose work could not be cited due to space limitations.

\section{References}

Adachi M, Autry AE, Covington HE III, Monteggia LM. 2009. MeCP2-mediated transcription repression in the basolateral amygdala may underlie heightened anxiety in a mouse model of Rett syndrome. J Neurosci 29: 4218-4227.

Adamczyk A, Mejias R, Takamiya K, Yocum J, Krasnova IN, Calderon J, Cadet JL, Huganir RL, Pletnikov MV, Wang T. 2012. GluA3-deficiency in mice is associated with increased social and aggressive behavior and elevated dopamine in striatum. Behav Brain Res 229: 265-272.

Alarcón JM, Malleret G, Touzani K, Vronskaya S, Ishii S, Kandel ER, Barco A. 2004. Chromatin acetylation, memory, and LTP are impaired in $\mathrm{CBP}+/-$ mice: A model for the cognitive deficit in Rubinstein-Taybi syndrome and its amelioration. Neuron 24: 947-959.

Alberini CA, Chen DY. 2012. Memory enhancement: Consolidation, reconsolidation and insulin-like growth factor 2 . TINS 35: 274-283.

Allensworth M, Saha A, Reiter LT, Heck DH. 2011. Normal social seeking behavior, hypoactivity and reduced exploratory range in a mouse model of Angelman syndrome. BMC Genet 12: 7. doi: 10.1186/ 1471-2156-12-7.
American Psychiatric Association. 2000. Diagnostic and statistical manual of mental disorders, 4 th ed. Washington, DC.

Bader PL, Faizi M, Kim LH, Owen SF, Tadross MR, Alfa RW, Bett GC, Tsien RW, Rasmusson RL, Shamloo M. 2011. Mouse model of Timothy syndrome recapitulates triad of autistic traits. Proc Natl Acad Sci 108: $15432-15437$.

Bangash MA, Park JM, Melnikova T, Wang D, Jeon SK, Lee D, Syeda S, Kim J, Kouser M, Schwartz J, et al. 2011. Enhanced polyubiquitination of Shank3 and NMDA receptor in a mouse model of autism. Cell 145: $758-772$.

Baron-Cohen S. 2004. The cognitive neuroscience of autism. J Neurol Neurosurg Psychiatry 75: 945-948.

Baron-Cohen S. 2010. Empathizing, systemizing, and the extreme male brain theory of autism. Prog Brain Res 186: 167-175.

Ben-Ami Bartal I, Decety J, Mason P. 2011. Empathy and pro-social behavior in rats. Science 334: 1427-1430.

Bertelli M, Alushi B, Veicsteinas A, Jinnah HA, Micheli V. 2009. Gene expression and mRNA editing of serotonin receptor $2 \mathrm{C}$ in brains of HPRT gene knock-out mice, an animal model of Lesch-Nyhan disease. J Clin Neurosci 16: 1061-1063.

Betancur C. 2011. Etiological heterogeneity in autism spectrum disorders: More than 100 genetic and genomic disorders and still counting. Brain Res 22: $42-77$.

Bingol B, Sheng M. 2011. Deconstruction for reconstruction: The role of proteolysis in neural plasticity and disease. Neuron 69: 22-32.

Bishop SL, Lahvis GP. 2011. The autism diagnosis in translation: Shared affect in children and mouse models of ASD. Autism Res 4: $317-335$.

Blundell J, Tabuchi K, Bolliger MF, Blaiss CA, Brose N, Liu X, Südhof TC, Powell CM. 2009. Increased anxiety-like behavior in mice lacking the inhibitory synapse cell adhesion molecule neuroligin 2. Genes Brain Behav 8: 114-126.

Bourtchouladze R, Lidge R, Catapano R, Stanley J, Gossweiler S, Romashko D, Scott R, Tully T. 2003. A mouse model of Rubinstein-Taybi syndrome: Defective long-term memory is ameliorated by inhibitors of phosphodiesterase 4. Proc Natl Acad Sci 100: $10518-10522$.

Bozdagi O, Sakurai T, Papapetrou D, Wang X, Dickstein DL, Takahashi N, Kajiwara Y, Yang M, Katz AM, Scattoni ML, et al. 2010. Neuroligin-1 deletion results in impaired spatial memory and increased repetitive behavior. J Neurosci 30: 2115-2129.

Calfa G, Percy AK, Pozzo-Miller L. 2011. Experimental models of Rett syndrome based on Mecp2 dysfunction. Exp Biol Med (Maywood) 236: 3-19.

Ceballos-Picot I, Mockel L, Potier MC, Dauphinot L, Shirley TL, Torero-Ibad R, Fuchs J, Jinnah HA. 2009. Hypoxanthine-guanine phosphoribosyl transferase regulates early developmental programming of dopamine neurons: Implications for Lesch-Nyhan disease pathogenesis. Hum Mol Genet 18: 2317-2327.

Chao HT, Chen H, Samaco RC, Xue M, Chahrour M, Yoo J, Neul JL, Gong S, Lu HC, Heintz N, et al. 2010. Dysfunction in GABA signalling mediates autism-like stereotypies and Rett syndrome phenotypes. Nature 11: $263-269$.

Chauhan A, Gu F, Essa MM, Wegiel J, Kaur K, Brown WT, Chauhan V. 2011. Brain region-specific deficit in mitochondrial electron transport chain complexes in children with autism. J Neurochem 117: 209-220.

Chen RZ, Akbarian S, Tudor M, Jaenisch R. 2001. Deficiency of methyl-CpG binding protein-2 in CNS neurons results in a Rett-like phenotype in mice. Nat Genet 27: 327-323.

Chen PC, Wakimoto H, Conner D, Araki T, Yuan T, Roberts A, Seidman C, Bronson R, Neel B, Seidman JG, et al. 2010. Activation of multiple signaling pathways causes developmental defects in mice with a Noonan syndrome-associated Sos 1 mutation. J Clin Invest 120: 4353-4365.

Cheng EP, Yuan C, Navedo MF, Dixon RE, Nieves-Cintrón M, Scott JD, Santana LF. 2011. Restoration of normal L-type Ca2 + channel function during Timothy syndrome by ablation of an anchoring protein. Circ Res 22: $255-261$.

Chévere-Torres I, Kaphzan H, Bhattacharya A, Kang A, Maki JM, Gambello MJ, Arbiser JL, Santini E, Klann E. 2012. Metabotropic glutamate receptor-dependent long-term depression is impaired due to elevated ERK signaling in the $\Delta \mathrm{RG}$ mouse model of tuberous sclerosis complex. Neurobiol Dis 45: 1101-1110.

Collins AL, Levenson JM, Vilaythong AP, Richman R, Armstrong DL, Noebels JL, David Sweatt J, Zoghbi HY. 2004. Mild overexpression of $\mathrm{MeCP} 2$ causes a progressive neurological disorder in mice. Hum $\mathrm{Mol}$ Genet 13: 2679-2689.

Cox MM, Tucker AM, Tang T, Talbot T, Richer DC, Yeh L, Arnold SE. 2009. Neurobehavioral abnormalities in the dysbindin-1 mutant, sandy, on a C57BL/6J genetic background. Genes Brain Behav 8: 390-397.

Crawley JN. 2007. What's wrong with my mouse? Behavioral phenotyping of transgenic and knockout mice, 2nd ed. John Wiley and Sons, Inc., New Jersey. 
Dahlhaus R, El-Husseini A. 2010. Altered neuroligin expression is involved in social deficits in a mouse model of the fragile X syndrome. Behav Brain Res 208: 96-105.

Dahlhaus R, Hines RM, Eadie BD, Kannangara TS, Hines DJ, Brown CE, Christie BR, El-Husseini A. 2010. Overexpression of the cell adhesion protein neuroligin-1 induces learning deficits and impairs synaptic plasticity by altering the ratio of excitation to inhibition in the hippocampus. Hippocampus 20: 305-322.

De Felice C, Signorini C, Durand T, Ciccoli L, Leoncini S, D'Esposito M, Filosa S, Oger C, Guy A, Bultel-Poncé V, et al. 2012. Partial rescue of Rett syndrome by $\omega-3$ polyunsaturated fatty acids (PUFAs) oil. Genes Nutr. doi: $10.1007 / \mathrm{s} 12263-012-0285-7$

Dhillon S, Hellings JA, Butler MG. 2011. Genetics and mitochondrial abnormalities in autism spectrum disorders: A review. Curr Genom 12: $322-332$

Di Nardo A, Kramvis I, Cho N, Sadowski A, Meikle L, Kwiatkowski DJ, Sahin M. 2009. Tuberous sclerosis complex activity is required to control neuronal stress responses in an mTOR-dependent manner. J Neurosci 29: 5926-5937.

Ehninger D, Han S, Shilyansky C, Zhou Y, Li W, Kwiatkowski DJ, Ramesh V, Silva AJ. 2008. Reversal of learning deficits in a Tsc2 + / - mouse model of tuberous sclerosis. Nat Med 14: 843-848.

Ehninger D, Sano Y, de Vries PJ, Dies K, Franz D, Geschwind DH, Kaur M, Lee YS, Li W, Lowe JK, et al. 2012. Gestational immune activation and Tsc2 haploinsufficiency cooperate to disrupt fetal survival and may perturb social behavior in adult mice. Mol Psychiatry 17: 62-70.

Etherton MR, Blaiss CA, Powell CM, Südhof TC. 2009. Mouse neurexin- $1 \alpha$ deletion causes correlated electrophysiological and behavioral changes consistent with cognitive impairments. Proc Natl Acad Sci 106: 17998-18003.

Fischer J, Hammerschmidt K. 2011. Ultrasonic vocalizations in mouse models for speech and socio-cognitive disorders: Insights into the evolution of vocal communication. Genes Brain Behav 10: 17-27.

Frustaci A, Neri M, Cesario A, Adams JB, Domenici E, Dalla Bernardina B, Bonassi S. 2012. Oxidative stress-related biomarkers in autism: Systematic review and meta-analyses. FreeRadic Biol Med 52: 2128-2141.

Fujita E, Dai H, Tanabe Y, Zhiling Y, Yamagata T, Miyakawa T, Tanokura M, Momoi MY, Momoi T. 2010. Autism spectrum disorder is related to endoplasmic reticulum stress induced by mutations in the synaptic cell adhesion molecule, CADM1. Cell Death Dis 1: e47. doi: 10.1038/ cddis. 2010.23.

Gemelli T, Berton O, Nelson ED, Perrotti LI, Jaenisch R, Monteggia LM. 2006. Postnatal loss of methyl-CpG binding protein 2 in the forebrain is sufficient to mediate behavioral aspects of Rett syndrome in mice. Biol Psychiatry 59: 468-476.

Gitiaux C, Ceballos-Picot I, Marie S, Valayannopoulos V, Rio M, Verrieres S, Benoist JF, Vincent MF, Desguerre I, Bahi-Buisson N. 2009. Misleading behavioural phenotype with adenylosuccinate lyase deficiency. Eur $J$ Hum Genet 17: 133-136.

Goebel-Goody SM, Wilson-Wallis ED, Royston S, Tagliatela SM, Naegele JR, Lombroso PJ. 2012. Genetic manipulation of STEP reverses behavioral abnormalities in a fragile X syndrome mouse model. Genes Brain Behav doi: $10.1111 / \mathrm{j} .1601-183 X 2012.00781$.

Grant SN. 2012. Synaptopathies: diseases of the synaptome. Curr Opin Neurobiol (in press). doi: 10.1016/j.conb.2012.02.002.

Gross C, Berry-Kravis EM, Bassell GJ. 2012. Therapeutic strategies in Fragile $\mathrm{X}$ Syndrome: Dysregulated mGluR signaling and beyond. Neuropsychopharmacology 37: 178-195.

Gu Y, Mcllwain KL, Weeber EJ, Yamagata T, Xu B, Antalffy BA, Reyes C, Yuva-Paylor L, Armstrong D, Zoghbi H, et al. 2002. Impaired conditioned fear and enhanced long-term potentiation in Fmr2 knock-out mice. J Neurosci 22: 2753-2763.

Guo X, Hamilton PJ, Reish NJ, Sweatt JD, Miller CA, Rumbaugh G. 2009 Reduced expression of the NMDA receptor-interacting protein SynGAP causes behavioral abnormalities that model symptoms of Schizophrenia. Neuropsychopharmacology 34: 1659-1672.

Guy J, Hendrich B, Holmes M, Martin JE, Bird A. 2001. A mouse Mecp2-null mutation causes neurological symptoms that mimic Rett syndrome. Nat Genet 27: 322-326.

Guy J, Gan J, Selfridge J, Cobb S, Bird A. 2007. Reversal of neurological defects in a mouse model of Rett syndrome. Science 315: 1143-1147.

Hebert DN, Molinari M. 2007. In and out of the ER: Protein folding, quality control, degradation, and related human diseases. Physiol Rev 87: $1377-1408$

Hines RM, Wu L, Hines DJ, Steenland H, Mansour S, Dahlhaus R, Singaraja RR, Cao X, Sammler E, Hormuzdi SG, et al. 2008. Synaptic imbalance, stereotypies, and impaired social interactions in mice with altered neuroligin 2 expression. J Neurosci 28: 6055-6067.

Hoeffer CA, Klann E. 2010. mTORC signaling: At the cross-roads of plasticity, memory and disease. Trends Neurosci 33: 67-75.

Hu D, Cao P, Thiels E, Chu CT, Wu GY, Oury TD, Klann E. 2007. Hippocampal long-term potentiation, memory, and longevity in mice that overexpress mitochondrial superoxide dismutase. Neurobiol Learn Mem 87: 372-384

Hutchinson AN, Deng JV, Aryal DK, Wetsel WC, West AE. 2012. Differential regulation of MeCP2 phosphorylation in the CNS by dopamine and serotonin. Neuropsychopharmacol 37: 321-337.

Jamain S, Radyushkin K, Hammerschmidt K, Granon S, Boretius S, Varoqueaux F, Ramanantsoa N, Gallego J, Ronnenberg A, Winter D, et al. 2008. Reduced social interaction and ultrasonic communication in a mouse model of monogenic heritable autism. Proc Natl Acad Sci 105: $1710-1715$

Jiang YH, Armstrong D, Albrecht U, Atkins CM, Noebels JL, Eichele G, Sweatt JD, Beaudet AL. 1998. Mutation of the Angelman ubiquitin ligase in mice causes increased cytoplasmic p53 and deficits of contextual learning and long-term potentiation. Neuron 21: 799-811.

Jiang YH, Pan Y, Zhu L, Landa L, Yoo J, Spencer C, Lorenzo I, Brilliant M, Noebels J, Beaudet AL. 2010. Altered ultrasonic vocalization and impaired learning and memory in Angelman syndrome mouse model with a large maternal deletion from Ube3a to Gabrb3. PLoS One 5: e12278. doi: 10.1371/journal.pone.0012278.

Jin P, Zarnescu DC, Ceman S, Nakamoto M, Mowrey J, Jongens TA, Nelson DL, Moses K, Warren ST. 2004. Biochemical and genetic interaction between the fragile $\mathrm{X}$ mental retardation protein and the microRNA pathway. Nat Neurosci 7: 113-117.

Josselyn SA. 2005. What's right with my mouse model? New insights into the molecular and cellular basis of cognition from mouse models of Rubinstein-Taybi Syndrome. Learn Mem 12: 80-83.

Kamat PK, Tota S, Shukla R, Ali S, Najmi AK, Nath C. 2011. Mitochondrial dysfunction: A crucial event in okadaic acid (ICV) induced memory impairment and apoptotic cell death in rat brain. Pharmacol Biochem Behav 100: 311-319.

Kao DI, Aldridge GM, Weiler IJ, Greenough WT. 2010. Altered mRNA transport, docking, and protein translation in neurons lacking fragile X mental retardation protein. Proc Natl Acad Sci 107: $15601-15606$.

Kaphzan H, Hernandez P, Jung JI, Cowansage KK, Deinhardt K, Chao MV, Abel T, Klann E. 2012. Reversal of impaired hippocampal long-term potentiation and contextual fear memory deficits in angelman syndrome model mice by ErbB inhibitors. Biol Psychiatry. doi: 10.1016/ j.biopsych.2012.01.021.

Karlsgodt KH, Robleto K, Trantham-Davidson H, Jairl C, Cannon TD, Lavin A, Jentsch JD. 2011. Reduced dysbindin expression mediates $\mathrm{N}$-methyl-D-aspartate receptor hypofunction and impaired working memory performance. Biol Psychiatry 69: 28-34.

Kelleher RJ III, Bear MF. 2008. The autistic neuron: Troubled translation? Cell 31: 401-406.

Kent L, Bowdin S, Kirby GA, Cooper WN, Maher ER. 2008. Beckwith Weidemann syndrome: A behavioral phenotype-genotype study. Am J Med Genet B Neuropsychiatr Genet 147B: 1295-1297.

Khelfaoui M, Denis C, van Galen E, de Bock F, Schmitt A, Houbron C, Morice E, Giros B, Ramakers G, Fagni L, et al. 2007. Loss of X-linked mental retardation gene oligophrenin1 in mice impairs spatial memory and leads to ventricular enlargement and dendritic spine immaturity. J Neurosci 29: 9439-9450.

Klejbor I, Kucinski A, Wersinger SR, Corso T, Spodnik JH, Dziewiatkowski J, Moryś J, Hesse RA, Rice KC, Miletich R, et al. 2009. Serotonergic hyperinnervation and effective serotonin blockade in an FGF receptor developmental model of psychosis. Schizophr Res 113: 308-321.

Korade Z, Kenworthy AK. 2008. Lipid rafts, cholesterol, and the brain. Neuropharmacology 55: 1265-1273.

Kumar RA. 2010. SHANK2 redemption: Another synaptic protein for mental retardation and autism. Clin Genet 78: 519-521.

Kwon CH, Luikart BW, Powell CM, Zhou J, Matheny SA, Zhang W, Li Y, Baker SJ, Parada LF. 2006. Pten regulates neuronal arborization and social interaction in mice. Neuron 50: $377-388$.

Laarakker MC, Reinders NR, Bruining H, Ophoff RA, Kas MJ. 2012. Sex-dependent novelty response in neurexin- $1 \alpha$ mutant mice. PLoS One 7: e31503. doi: 10.1371/journal.pone.0031503.

Lalande M, Calciano MA. 2007. Molecular epigenetics of Angelman syndrome. Cell Mol Life Sci 64: 947-960.

Laureys G, Barton DE, Ullrich A, Francke U. 1988. Chromosomal mapping of the gene for the type II insulin-like growth factor receptor/ cation-independent mannose 6-phosphate receptor in man and mouse. Genomics 3: 224-229.

Lee SH, Choi JH, Lee N, Kim JL, Yu NK, Choi SL, Lee SH, Kim H, Kaang BK. 2008. Synaptic protein degradation underlies destabilization of retrieved fear memory. Science 319: 1253-1256.

Leoncini S, De Felice C, Signorini C, Pecorelli A, Durand T, Valacchi G, Ciccoli L, Hayek J. 2011. Oxidative stress in Rett syndrome: Natural history, genotype, and variants. Redox Rep 16: 145-153.

Li Y, Li Y, McKay RM, Riethmacher D, Parada LF. 2012. Neurofibromin modulates adult hippocampal neurogenesis and behavioral effects of antidepressants. J Neurosci 32: 3529-3539. 
Liu-Yesucevitz L, Bassell GJ, Gitler AD, Hart AC, Klann E, Richter JD, Warren ST, Wolozin B. 2011. Local RNA translation at the synapse and in disease. J Neurosci 31: 16086-16093.

Lodish H, Berk A, Kaiser CA, Krieger M, Scott MP, Bretscher A, Ploegh H, Matsudaira P. 2008. Molecular cell biology. W.H. Freeman \& Company, New York.

Lopez-Salon M, Alonso M, Vianna MR, Viola H, Mello e Souza T, Izquierdo I, Pasquine JM, Medina JH. 2001. The ubiquitin-proteasome cascade is required for mammalian long-term memory formation. Eur J Neurosci 14: 1820-1826.

Manzi B, Loizzo AL, Giana G, Curatolo P. 2008. Autism and metabolic diseases. J Child Neurol 23: 307-314.

Marley A, von Zastrow M. 2010. Dysbindin promotes the post-endocytic sorting of Gprotein-coupled receptors to lysosomes. PLoS One 5: e9325. doi: 10.1371 /journal.pone.0009325.

Massaad CA, Klann E. 2011. Reactive oxygen species in the regulation of synaptic plasticity and memory. Antioxid Redox Signal 14: 2013-2054

Maul B, von Bohlen und Halbach O, Becker A, Sterner-Kock A, Voigt JP, Siems WE, Grecksch G, Walther T. 2008. Impaired spatial memory and altered dendritic spine morphology in angiotensin II type 2 receptor-deficient mice. J Mol Med (Berl) 86: 563-571.

McPartland JC, Coffman M, Pelphrey KA. 2011. Recent advances in understanding the neural bases of autism spectrum disorder. Curr Opi Pediatrics 23: 628-632.

Mejias R, Adamczyk A, Anggono V, Niranjan T, Thomas GM, Sharma K, Skinner C, Schwartz CE, Stevenson RE, Fallin MD, et al. 2011. Gain-of-function glutamate receptor interacting protein 1 variants alter GluA2 recycling and surface distribution in patients with autism. Proc Natl Acad Sci 108: 4920-4925.

Melko M, Bardoni B. 2010. The role of G-quadruplex in RNA metabolism: Involvement of FMRP and FMR2P. Biochimie 92: 919-926.

Mines MA, Yuskaitis CJ, King MK, Beurel E, Jope RS. 2010. GSK3 influences social preference and anxiety-related behaviors during social interaction in a mouse model of fragile $\mathrm{X}$ syndrome and autism. PLOS One 5: e9706. doi: 10.1371/journal.pone.0009706.

Miura K, Kishino T, Li E, Webber H, Dikkes P, Holmes GL, Wagstaff J. 2002. Neurobehavioral and electroencephalographic abnormalities in Ube3a maternal-deficient mice. Neurobiol Dis 9: 149-159.

Morabito MV, Abbas AI, Hood JL, Kesterson RA, Jacobs MM, Kump DS, Hachey DL, Roth BL, Emeson RB. 2010. Mice with altered serotonin 2C receptor RNA editing display characteristics of Prader-Willi syndrome. Neurobiol Dis 39: 169-180.

Moretti P, Levenson JM, Battaglia F, Atkinson R, Teague R, Antalffy B, Armstrong D, Arancio O, Sweatt JD, Zoghbi HY. 2006. Learning and memory and synaptic plasticity are impaired in a mouse model of Rett syndrome. J Neurosci 26: 319-327.

Muhia M, Feldon J, Knuesel I, Yee BK. 2009. Appetitively motivated instrumental learning in SynGAP heterozygous knockout mice. Behav Neurosci 123: 1114-1128.

Muhia M, Yee BK, Feldon J, Markopoulos F, Knuesel I. 2010. Disruption of hippocampus-regulated behavioural and cognitive processes by heterozygous constitutive deletion of SynGAP. Eur J Neurosci 31: $529-543$.

Na ES, Nelson ED, Adachi M, Autry AE, Mahgoub MA, Kavalali ET, Monteggia LM. 2012. A mouse model for MeCP2 duplication syndrome: MeCP2 overexpression impairs learning and memory and synaptic transmission. Nat Genet 8: 206-211.

Nava C, Hanna N, Michot C, Pereira S, Pouvreau N, Niihori T, Aoki Y, Matsubara Y, Arveiler B, Lacombe D, et al. 2007. Cardio-facio-cutaneous and Noonan syndromes due to mutations in the RAS/MAPK signalling pathway: Genotype-phenotype relationships and overlap with Castello Syndrome. J Med Genet 44: 763-771.

Neves-Pereira M, Müller B, Massie D, Williams JH, O'Brien PC, Hughes A, Shen SB, Clair DS, Miedzybrodzka Z. 2009. Deregulation of EIF4E: A novel mechanism for autism. J Med Genet 46: 759-765.

Nyhan WL, O'Neill JP, Jinnah HA, Harris JC. 2000. Lesch-Nyhan Syndrome. In GeneReview (ed. RA Pagon, et al.). University of Washington, Seattle, WA.

O'Brien WT, Xu G, Batta A, Tint GS, Salen G, Dyer CA, Kendler A, Servatius RJ. 2002. Developmental sensitivity of associative learning to cholesterol synthesis inhibitors. Behav Brain Res 129: $141-152$.

Ogiwara I, Miyamoto H, Morita N, Atapour N, Mazaki E, Inoue I, Takeuchi T, Itohara S, Yanagawa Y, Obata K, et al. 2007. Nav1.1 localizes to axons of parvalbumin-positive inhibitory interneurons: A circuit basis for epileptic seizures in mice carrying an Scn1a gene mutation. J Neurosci 27: 5903-5914.

Otte DM, Sommersberg B, Kudin A, Guerrero C, Albayram O, Filiou MD, Frisch P, Yilmaz O, Drews E, Turck CW, et al. 2011. N-acetyl cysteine treatment rescues cognitive deficits induced by mitochondrial dysfunction in G72/G30 transgenic mice. Neuropsychopharmacology 36: 2233-2243.
Palmieri L, Papaleo V, Porcelli V, Scarcia P, Gaita L, Sacco R, Hager J, Rousseau F, Curatolo P, Manzi B, et al. 2010. Altered calcium homeostasis in autism-spectrum disorders: Evidence from biochemical and genetic studies of the mitochondrial aspartate/glutamate carrier AGC1. Mol Psychiatry 15: $38-52$.

Panksepp JB, Lahvis GP. 2011. Rodent empathy and affective neuroscience. Neurosci Biobehav Rev 35: 1864-1875.

Park S, Park JM, Kim S, Kim JA, Shepherd JD, Smith-Hicks CL, Chowdhury S, Kaufmann W, Kuhl D, Ryazanov AG, et al. 2008. Elongation factor 2 and fragile X mental retardation protein control the dynamic translation of Arc/Arg3.1 essential for mGluR-LTD. Neuron 59: 70-83.

Pelc K, Cheron G, Dan B. 2008. Behavior and neuropsychiatric manifestations in Angelman syndrome. Neuropsychiatr Dis Treat 4: 577-584.

Peñagarikano O, Abrahams BS, Herman EI, Winden KD, Gdalyahu A, Dong H, Sonnenblick LI, Gruver R, Almajano J, Bragin A, et al. 2011. Absence of CNTNAP2 leads to epilepsy, neuronal migration abnormalities, and core autism-related deficits. Cell 147: 235-246.

Pindolia K, Jordan M, Guo C, Matthews N, Mock DM, Strovel E, Blitzer M, Wolf B. 2011. Development and characterization of a mouse with profound biotinidase deficiency: A biotin-responsive neurocutaneous disorder. Mol Genet Metab 102: 161-169.

Qualmann B, Koch D, Kessels M. 2011. Let's go bananas: Revisiting the endocytic BAR code. EMBO J 30: 3501-3515.

Radyushkin K, Hammerschmidt K, Boretius S, Varoqueaux F, El-Kordi A, Ronnenberg A, Winter D, Frahm J, Fischer J, Brose N, et al. 2009. Neuroligin-3-deficient mice: Model of a monogenic heritable form of autism with an olfactory deficit. Genes Brain Behav $\mathbf{8}$ : $416-425$.

Ramakers GJ, Wolfer D, Rosenberger G, Kuchenbecker K, Kreienkamp HJ, Prange-Kiel J, Rune G, Richter K, Langnaese K, Masneuf S, et al. 2012. Dysregulation of Rho GTPases in the $\alpha$ Pix/Arhgef 6 mouse model of $\mathrm{X}$-linked intellectual disability is paralleled by impaired structural and synaptic plasticity and cognitive deficits. Hum Mol Genet 15: $268-286$.

Rammal H, Bouayed J, Soulimani R. 2010. A direct relationship between aggressive behavior in the resident/intruder test and cell oxidative status in adult male mice. Eur J Pharmacol 627: 173-176.

Ropers HH. 2010. Genetics of early onset cognitive impairment. Annu Rev Genomics Hum Genet 11: 161-187.

Rossignol DA, Frye RE. 2012. Mitochondrial dysfunction in Autism Spectrum Disorders: A systematic review and meta-analysis. Mol Psych 17: $290-314$

Ross-Inta C, Omanska-Klusek A, Wong S, Barrow C, Garcia-Arocena D, Iwahashi C, Berry-Kravis E, Hagerman RJ, Hagerman PJ, Giulivi C. 2010 Evidence of mitochondrial dysfunction in fragile X-associated tremor/ ataxia syndrome. Biochem J 429: 545-552.

Rotschafer SE, Trujillo MS, Dansie LE, Ethell IM, Razak KA. 2012. Minocycline treatment reverses ultrasonic vocalization production deficit in a mouse model of Fragile X Syndrome. Brain Res 23: 7-14

Roubertoux PL, Sluyter F, Carlier M, Marcet B, Maarouf-Veray F, Chérif C, Marican C, Arrechi P, Godin F, Jamon M, et al. 2003. Mitochondrial DNA modifies cognition in interaction with the nuclear genome and age in mice. Nat Gen 35: 65-69.

Rubenstein JL. 2011. Annual Research Review: Development of the cerebral cortex: Implications for neurodevelopmental disorders. J Child Psychol Psychiatry 52: 339-355.

Rudenko O, Tkach V, Berezin V, Bock E. 2010. Effects of FGF receptor peptide agonists on animal behavior under normal and pathological conditions. Neurosci Res 68: 35-43.

Rutter M. 1970. Autistic children: Infancy to adulthood. Semin Psychiatry 2: $435-450$.

Rutter M, Bartak L. 1973. Special educational treatment of autistic children: A comparative study. II. Follow-up findings and implications for services. J Child Psychol Psychiatry 14: 241-270.

Sadakata T, Washida M, Iwayama Y, Shoji S, Sato Y, Ohkura T, Katoh-Semba R, Nakajima M, Sekine Y, Tanaka M, et al. 2007. Autistic-like phenotypes in Cadps2-knockout mice and aberrant CADPS2 splicing in autistic patients. J Clin Invest 117: 931-943.

Sadakata T, Sekine Y, Oka M, Itakura M, Takahashi M, Furuichi T. 2012. Calcium-dependent activator protein for secretion 2 interacts with the class 2 ARF small GTPases and regulates dense-core vesicle trafficking. FEBS J 279: 384-394.

Sajdel-Sulkowska EM, Xu M, McGinnis W, Koibuchi N. 2011. Brain region-specific changes in oxidative stress and neurotrophin levels in autism spectrum disorders (ASD). Cerebellum 10: 43-48.

Sakurai M, Sekiguchi M, Zushida K, Yamada K, Nagamine S, Kabuta T, Wada K. 2008. Reduction in memory in passive avoidance learning, exploratory behaviour and synaptic plasticity in mice with a spontaneous deletion in the ubiquitin C-terminal hydrolase L1 gene. Eur J Neurosci 27: 691-701.

Samaco RC, Mandel-Brehm C, Chao HT, Ward CS, Fyffe-Maricich SL, Ren J, Hyland K, Thaller C, Maricich SM, Humphreys P, et al. 2009. Loss of 
MeCP2 in aminergic neurons causes cell-autonomous defects in neurotransmitter synthesis and specific behavioral abnormalities. Proc Natl Acad Sci 106: 21966-21971.

Samaco RC, Mandel-Brehm C, McGraw CM, Shaw CA, McGill BE, Zoghbi HY. 2012. Crh and Oprm1 mediate anxiety-related behavior and social approach in a mouse model of MECP2 duplication syndrome. Nat Genet 8: 206-211.

Sartori S, Anesi L, Polli R, Toldo I, Casarin A, Drigo P, Murgia A. 2008. Angelman syndrome due to a novel splicing mutation of the UBE3A gene. J Child Neurol 23: 912-915.

Shahbazian M, Young J, Yuva-Paylor L, Spencer C, Antalffy B, Noebels J, Armstrong D, Paylor R, Zoghbi H. 2002. Mice with truncated MeCP2 recapitulate many Rett syndrome features and display hyperacetylation of histone H3. Neuron 18: 243-254.

Shi J, Zhang T, Zhou C, Chohan MO, Gu X, Wegiel J, Zhou J, Hwang YW, Iqbal K, Grundke-Iqbal I, et al. 2008. Increased dosage of Dyrk1A alters alternative splicing factor (ASF)-regulated alternative splicing of tau in Down syndrome. J Biol Chem 283: 28660-28669.

Shilyansky C, Karlsgodt KH, Cummings DM, Sidiropoulou K, Hardt M, James AS, Ehninger D, Bearden CE, Poirazi P, Jentsch JD, et al. 2010. Neurofibromin regulates corticostriatal inhibitory networks during working memory performance. Proc Natl Acad Sci 107: 13141-13146.

Sikora DM, Pettit-Kekel K, Penfield J, Merkens LS, Steiner RD. 2006. The near universal presence of autism spectrum disorders in children with Smith-Lemli-Opitz syndrome. Am J Med Genet A 140: 1511-1518.

Silverman JL, Yang M, Lord C, Crawley JN. 2010a. Behavioural phenotyping assays for mouse models of autism. Nat Rev Neurosci 11: $490-502$.

Silverman JL, Turner SM, Barkan CL, Tolu SS, Saxena R, Hung AY, Sheng M, Crawley JN. 2010b. Sociability and motor functions in Shank1 mutant mice. Brain Res 1380: $120-137$.

Smith SEP, Zhou YD, Zhang G, Jin Z, Stoppel DC, Anderson MP. 2011. Increased gene dosage of Ube3a results in autism traits and decreased glutamate synaptic transmission in mice. Sci Transl Med 3: 103ra97. doi: 10.1126/scitranslmed.3002627.

Splawski I, Timothy KW, Sharpe LM, Decher N, Kumar P, Bloise R, Napolitano C, Schwartz PJ, Joseph RM, Condouris K, et al. 2004. $\mathrm{Ca}(\mathrm{V}) 1.2$ calcium channel dysfunction causes a multisystem disorder including arrhythmia and autism. Cell 119: 19-31.

Stettner GM, Shoukier M, Höger C, Brockmann K, Auber B. 2011. Familial intellectual disability and autistic behavior caused by a small FMR2 gene deletion. Am J Med Genet A 155A: 2003-2007.

Strømme P, Dobrenis K, Sillitoe RV, Gulinello M, Ali NF, Davidson C, Micsenyi MC, Stephney G, Ellevog L, Klungland A, et al. 2011. X-linked Angelman-like syndrome caused by Slc9a6 knockout in mice exhibits evidence of endosomal-lysosomal dysfunction. Brain 134: 3369-3383.

Tabuchi K, Blundell J, Etherton MR, Hammer RE, Liu X, Powell CM, Südhof TC. 2007. A neuroligin-3 mutation implicated in autism increases inhibitory synaptic transmission in mice. Science 318: 71-76.

Tai HC, Schuman EM. 2008. Ubiquitin, the proteasome and protein degradation in neuronal function and dysfunction. Nat Rev Neurosci 9: $826-838$

Vaillend C, Ungerer A. 1999. Behavioral characterization of mdx3cv mice deficient in C-terminal dystrophins. Neuromuscul Disord 9: 296-304.

Vaillend C, Billard JM, Laroche S. 2004. Impaired long-term spatial and recognition memory and enhanced CA1 hippocampal LTP in the dystrophin-deficient Dmd(mdx) mouse. Neurobiol Dis 17: 10-20.

van Bokhoven H. 2011. Genetic and epigenetic networks in intellectual disabilities. Annu Rev Genet 45: 81-104.

van Woerden GM, Harris KD, Hojjati MR, Gustin RM, Qiu S, de Avila Freire R, Jiang YH, Elgersma Y, Weeber EJ. 2007. Rescue of neurological deficits in a mouse model for Angelman syndrome by reduction of $\alpha$-CamKII inhibitory phosphorylation. Nat Neuro 10: 280-282.
Wang J, Weaver IC, Gauthier-Fisher A, Wang H, He L, Yeomans J Wondisford F, Kaplan DR, Miller FD. 2010a. CBP histone acetyltransferase activity regulates embryonic neural differentiation in the normal and Rubinstein-Taybi syndrome brain. Dev Cell 19: $114-125$.

Wang X, McCoy PA, Rodriguiz RM, Pan Y, Je HS, Roberts AC, Kim CJ, Berrios J, Colvin JS, Bousquet-Moore D, et al. 2010b. Synaptic dysfunction and abnormal behaviors in mice lacking major isoforms of Shank3. Hum Mol Genet 20: 3093-3108.

Weaving LS, Christodoulou J, Williamson SL, Friend KL, McKenzie OL, Archer H, Evans J, Clarke A, Pelka GJ, Tam PP, et al. 2004. Mutations of CDKL5 cause a severe neurodevelopmental disorder with infantile spasms and mental retardation. Am J Hum Genet 75: 1079-1093.

Wing L. 1981. Asperger's syndrome: A clinical account. Psychol Med 11: $115-129$.

Wöhr M, Roullet FI, Hung AY, Sheng M, Crawley JN. 2011. Communication impairments in mice lacking Shank1: Reduced levels of ultrasonic vocalizations and scent marking behavior. PLoS One 6: e20631. doi: 10.1371/journal.pone.0020631.

Wood MA, Kaplan MP, Park A, Blanchard EJ, Oliveira AM, Lombardi TL, Abel T. 2005a. Transgenic mice expressing a truncated form of CREB-binding protein (CBP) exhibit deficits in hippocampal synaptic plasticity and memory storage. Learn Mem 12: 111-119.

Wood MA, Kaplan MP, Brensinger C, Guo W, Abel T. 2005b. Ubiquitin C-terminal hydrolase L3 (Uchl3) is involved in working memory. Hippocampus 15: 610-621.

World Health Organization. 2004. International statistical classification of diseases and health related problems. Geneva, Switzerland.

Wu X, Simpson J, Hong JH, Kim KH, Thavarajah NK, Backx PH, Neel BG, Araki T. 2011. MEK-ERK pathway modulation ameliorates disease phenotypes in a mouse model of Noonan syndrome associated with the Raf1(L613V) mutation. J Clin Invest 121: 1009-1025.

Xu G, Servatius RJ, Shefer SG, Stephen Tint GS, O'Brien WT, Batta AK, Salen G. 1998. Relationship between abnormal cholesterol synthesis and retarded learning in rats. Metabolism 47: 878-882.

Xu L, Korade Z, Rosado Jr. DAJr, Liu W, Lamberson CR, Porter NA. 2011. An oxysterol biomarker for 7-dehydrocholesterol oxidation in cell/ mouse models for Smith-Lemli-Opitz syndrome. J Lipid Res 52: $1222-1233$.

Yang M, Bozdagi O, Scattoni ML, Wöhr M, Roullet FI, Katz AM, Abrams DN, Kalikhman D, Simon H, Woldeyohannes L, et al. 2012. Reduced excitatory neurotransmission and mild autism-relevant phenotypes in adolescent shank3 null mutant mice. J Neurosci 32: 6525-6541.

Young DM, Schenk AK, Yang SB, Jan YN, Jan LY. 2010. Altered ultrasonic vocalizations in a tuberous sclerosis mouse model of autism. Proc Natl Acad Sci 107: 11074-11079.

Zhang C, Milunsky JM, Newton S, Ko J, Zhao G, Maher TA, Tager-Flusberg H, Bolliger MF, Carter AS, Boucard AA, et al. 2009. A neuroligin-4 missense mutation associated with autism impairs neuroligin-4 folding and endoplasmic reticulum export. J Neurosci 29: 10843-10854.

Zhao M, Li D, Shimazu K, Zhou YX, Lu B, Deng CX. 2007. Fibroblast growth factor receptor-1 is required for long-term potentiation, memory consolidation, and neurogenesis. Biol Psychiatry 62: 381-390.

Zhou J, Blundell J, Ogawa S, Kwon CH, Zhang W, Sinton C, Powell CM, Parada LF. 2009. Pharmacological inhibition of mTORC1 suppresses anatomical, cellular, and behavioral abnormalities in neural-specific Pten knock-out mice. J Neurosci 29: 1773-1783.

Zhuravliova E, Barbakadze T, Zaalishvili E, Chipashvili M, Koshoridze N, Mikeladze D. 2009. Social isolation in rats inhibits oxidative metabolism, decreases the content of mitochondrial K-Ras and activates mitochondrial hexokinase. Behav Brain Res 205: 377-383.

Received April 19, 2012; accepted in revised form June 4, 2012. 


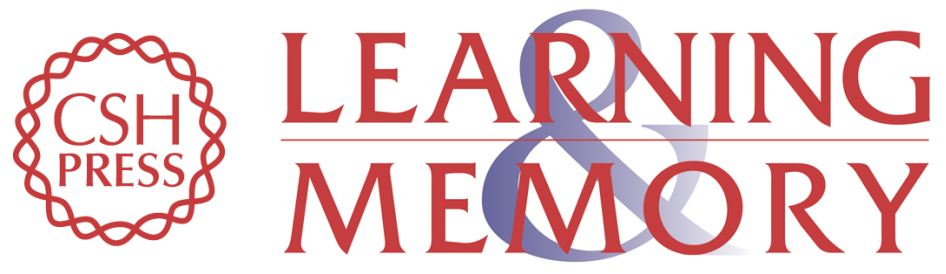

\section{The molecular basis of cognitive deficits in pervasive developmental disorders}

Aditi Bhattacharya and Eric Klann

Learn. Mem. 2012, 19:

Access the most recent version at doi:10.1101//m.025007.111

References This article cites 153 articles, 34 of which can be accessed free at:

http://learnmem.cshlp.org/content/19/9/434.full.html\#ref-list-1

License

Email Alerting Receive free email alerts when new articles cite this article - sign up in the box at the Service top right corner of the article or click here. 